\section{Sesam, Sesam, forskyd dig!}

Niels Brügger og Finn Frandsen (red.): Filosofiske forskydninger - en bog om Jean-François Lyotard. Akademisk forlag 1989. 216 sider, $172 \mathrm{kr}$.

Når "postmodernismen" er ved at gå af mode og løsenet "Lyotard" ikke længere er tilstrækkeligt for at få sesamportene til de intellektuelles "in-side" til at åbne sig, kan man enten sætte sin næse op efter nye løsener - eller roligt sætte sig ned og undres. Det er filosofiens time, eksperimenteringens ubestemte søgen. Når egennavnet Lyotard for "tiden, i dag" ikke duer som passepartout, så viser det hen til den uendelige "erstattelighed" ved egennavnets (referentens) betydning som kan ske ved enhver nytilkommen sætning (men som diskursgenrernes regelsystemer fors $\emptyset$ ger at dæmpe, af gode grunde). Besindelse på dette sublime spil mellem det velkendtes endelige (skønne) former og betydningernes (hæslige og groteske) uendelighed er en balancegang "auf des Messers Schneide". God filosofi i dag er den tænkning som hverken falder ned i den kedsommelige repetition af det altfor velkendte eller heroiserer det absolut ukendte som ny norm, men som administrerer sin balance $\varnothing$ konomi ligesom en karruselfører: går det for langsomt kedes man, går det for hurtigt bliver man kvalm; kunsten består $i$ at finde det punkt, hvor man beholder den vellystige svimmelhed, dvs. hvor man endnu kan følge med i meta- morfoserne mellem det kendte og ukendte, formen og det uformelige, bestemthed og ubestemthed, den gamle velkendte Lyotard og dette egennavns nye indspil. Balancekunsten mellem disse modpoler bærer hos Lyotard navnet "forskydning" og denne bog, der har sat sig for, om ikke at undgå "markedsskrigeriet", så dog at faldbyde kvalitetsvarer, har da også sat det motto på sin fane at ville foretage et stykke anamnesearbejde på de "filosofiske forskydninger" som Lyotards tekster har underløbet mellem og inden for de enkelte faser.

Således leverer Finn Frandsen, for et skandinavisk publikum, der sjældent har nåt at læse andet end Viden og det postmoderne samfund, en meget oplysende introduktion til og oversigt over de værker og faser som Lyotard har gennemløbet; en artikel, der både medtager de væsentlige problematikker og figurer, der er karakteristiske for den enkelte del af værket, deres skranker eller kritisable slagsider, samt de deraf følgende for-skydninger til næste "position". Et stykke eksemplarisk læsevejledningsarbejde der giver holdepunkter og læselyst til et nærmere studium, også af Lyotards tidligere arbejder. Især burde Discours, figure fra 1971 påkalde sig en (forsinket) læsning, ikke ud fra arkivariske, men højst aktuelle lyotardske overvejelser, ligesom hans kunst- og æstetikteoretiske engagement (der har været et konstant interessefelt hos ham helt tilbage fra læremesteren Merleau-Ponty) i det hele taget burde ofres større opmærksomhed. Derudover indeholder Frandsens artikel centrale overvejelser over "forskydningen" som filosofisk 
"position", samt filosofien som anamnese og "Durcharbeitung".

I sin artikel om Lyotards sprogopfattelse fors $\emptyset$ ger Niels Brügger at efterspore en mere specifik forskydning inden for Lyotards senere forfatterskab. I Viden og det postmoderne samfund havde der vist sig en indre apori i opfattelsen af sprogspillet: 1) Ethvert udsagn er at opfatte som et sprogspil, der placerer en afsender, en modtager og en referent. 2) Ethvert udsagn er at opfatte som noget, én af instanserne bruger til at slå slag med. Sprogspillene både placerer spillerne og bruges af disse. Og hvordan er forholdet mellem sammenvævningen af alle sprogspil og det enkelte sprogspil? Er denne sammenvæuning selv et nyt spil? Disse og en række andre spørgsmål fører Brügger til en præcisering af Lyotards sprogopfattelse. Først vises der hvordan pragmatikken i sprogspillet ikke er hentet fra Wittgenstein, men fra Roman Jakobsons kommunikationsmodel; derefter vises det hvordan Kants demarkation mellem erkendelse og idé, samt Heideggers Ereignis-begreb i Lyotards senere værk Le differend muliggør en distinktion mellem "sætningen som type" og "sætningen som begivenhed". Typologien fors $\emptyset$ ges bestemt gennem sætningsregimer og diskursgenrer, mens besindelsen på begivenhedskarakteren bringer et kritisk friktionselement ind over for pragmatikken. I sin meget velstrukturerede og oplysende artikel kan Brügger vise, hvordan de tidligere begreber om sprogspil som "udsagn" erstattes med "sætning", og sprogspil som "sammenvæuning" erstattes med "diskursgenre" samt at a- gonistikken erstattes med "striden". På den måde fastholdes fortsat pragmatikkens fors $\emptyset \mathrm{g}$ på bestemmelse af mindsteelementer, men nu på en sådan måde, at den tidligere antropocentrisme undgås og erstattes med en sætningsontologi. Afslutningsvis formulerer artiklen en mulig kritik af Lyotard for "glossacentrisme"; for at overeksponere sprogets betydning i relationen sprog/menneske, hvor Wittgenstein/ Heidegger endnu véd at fastholde begge poler i en samtidighed.

Det politiskes "sene" opdukken i Lyotards filosofi er temaet for Anne Sejtens artikel, der er en veritabel "kaloriebombe": stofmættet præcis. Den afgørende forskydning, der sker efter Economie libidinale, samler sig om legitimitets- og retfærdighedsproblemet. Men da enhver metaposition inden for det politiske felt er umuliggjort ved en tilgrundliggende heterogenitet, så er der i princippet ingen løsning på det politiske problem om retfærdighed og legitimitet. "Det politiske" er kun at fastholde som det åbne, uafklarede mødested for stridigheder mellem sætningsregimer og diskursgenrer. Til forskel fra "politikken", som er en diskursgenre blandt andre, angiver termen "det politiske" både en undtagelse og et fundament: undtagelse, fordi det politiske netop ikke kan bestemmes som en diskursgenre; fundament fordi det blotlægger en forudgående betingelse for diskursgenrernes virke. Det politiske er selve striden mellem diskursgenrerne. Derfor er det politiske ikke selv en diskursgenre; det ville betyde at den kun kunne være det som metadiskurs over alle de andre. Godt nok er alt politisk, $\mathrm{i}$ betydningen alle genrer 
strides, men politikken er ikke alt, forstået som den genre som indeholder alle andre.

Hvor diskursgenrerne angiver de regler som styrer sætningssammenkædninger inden for genren (f. eks. "den republikanske politik"), så henviser "det politiske" til den åbne mangel på regler i sammenkædningen mellem genrerne (f. eks. mellem politiske ideologier). Hvor genrernes formålsbestemmelse realiserer bestemte sammenkædninger, viser det politiske hen til andre, mulige sammenkædninger, der ikke blev realiseret, som forblev ubestemte og netop fortrængt, og at denne fortrængning er det grundlag, hvorpå genrerne etablerer deres beherskelse. Over for genrernes domesticering af det principielt åbne mulighedsfelt angiver det politiske kun et "negativt tegn" på denne underliggende sublime åbenhed. Denne paradoksale stærk-svage bestemmelse af det politiske belyser Sejten så i tre tempi, knyttet til de tre værker: Le différend, L'enthousiasme og Heidegger et "les juifs", hvor det politiske karakteriseres som henholdsvis usikkert, hjemløst og uforberedt. Afslutningsvis diskuteres, med udgangspunkt i striden mellem Lacoue-Labarthe og Lyotard, fors $\emptyset$ get på at gentænke det politiske hinsides den æstetiske formgivnings (græcisitetens) episteme, som nu, med "jøderne" som episteme synes at bringe et nyt problem på banen: at kunne skelne mellem det etiske og det politiske.

I en meget veloplagt og velskrevet artikel tager Kasper Olsen derefter fat på den lyotardske æstetik, eller mere præcist forskydningerne fra en æstetik til en anæstetik, der groft sagt svarer til forskydningerne mellem moderniteten og "det postmoderne vilkår", det skønne og det sublime, formen og det uudsigelige, aisthesis og anæstesi, græcisiteten og "det jødiske" m.m. Temaet er strengt bygget op ved en indledningsvis redegørelse for hvordan man skal forstå forholdet mellem modernitet/postmodernitet, dernæst en teorihistorisk gennemgang af æstetikkens opkomst (Baumgarten/Diderot/Burke/ Kant) og den heri indeholdte apori mellem forening og divergens, der viser hen til det sublime som en grænsebestemmelse ved det skønne, for så endeligt at knytte an til avantgardekunstens og Lyotards forskydning af det sublime over i en tidsanalytik, hvorved det først også bliver synligt hvor skellet mellem det romantisk sublime og det æstetisk moderne går. Bogens redaktører har da også rammende valgt en tekst - "Tiden, i dag" fra den sidste essayssamling L'in-humain - som den sidste (sammenkædede) sats til at profilere Lyotards seneste interessefelt.

Frederik Stjernfelt har haft ansvaret for at samle trådene til en etik hos Lyotard og det har han da også gjort på mesterlig vis. Også her foretages et kort tilbageblik for at vise hvordan den tidlige libidinalæstetik vanskeligt kunne skabe platform for etiske eller politiske overvejelser, hvorimod disse spørgsmål gradvis vokser frem i den paganistiske periode. Fra og med $A u$ juste bliver problemet om retfærdigheden påtrængende som et spørgsmål om respekt for heterogeniteten. Med denne etablering af en genuin etisk problemhorisont bliver Lyotards teoriudvikling bestemt gennem et 
krydstogt mellem Kants pligtetik og Levinas' jødiske etik. Paganismens dyrkelse af de mange guder og den pragmatiske forhandling mellem de små fortællinger omsætter Kants pligt-etik i en pragmatik. Ikke en universalpragmatik, som skal redegøre for og etablere de ensartede regler og betingelser for sproglig kommunikation, men blot en fastholdelse af retten til at kunne indtage enhver af de pragmatiske positioner. Den hegemoniske vidensdiskurs prioriterer afsenderen og referenten, og kommer derved til at begå uret imod andre diskursgenrer, som f.eks. den præskriptive, hvor modtageren indtager en speciel position. Ved et tilbagegreb til Kants etik, hvor det kategoriske imperativ af Lyotard tolkes som en dom uden kriterier, foretages en forskydning inden for Kants formulering: "Handl, så at (so dass) din maksime..." til et "Handl, som om (als ob) din maksime...", netop fordi formen "p så at d" fører en præskriptiv dom tilbage til en deskriptiv sætning. Som brækstang for denne Kant-kritik bruges Levinas' jødiske etiks påpegning af modtageren og modtagningens særlige betydning for den præskriptive dom. Jøderne modtager Loven (den Anden) før de anerkender (og begriber) dens indhold. Forholdet mellem jeg og du, selvet og den Anden er radikalt asymmetrisk. Den Andens blotte væren viser en fremmedhed, en uendelighed og et kategorisk påbud inden man overhovedet kan etablere en beskrivelse eller forståelse, ifølge Levinas. Lyotard accepterer dog ikke den præskriptive sætnings priviligerede stilling således som hos Levinas, den er blot een blandt mange.

I $A u$ juste er der imidlertid en uklarhed vedrørende terror. På den ene side er terroren en del af sprogspillet (agon) og på den anden side har Lyotard en forestilling om, at terroren bør forbydes som indsats, fordi den truer med at stoppe og ensrette spillet. Stjernfelts spørgsmål er så: hvad kan ideen om mangfoldighed overhovedet forbyde? Først med Le Différend skelnes der klart mellem de enkelte sætningstyper og de spil de indgår i (diskursgenre). Det etiske spørgsmål stiller sig her trefoldigt: 1) som et bestemt sætningsregime (præskription), 2) som en diskursgenre (at være retfærdig), 3) som et meta-spørgsmål, der rejses om forholdet mellem diskursgenrerne. Som igen måske kan formuleres i den første form osv. "Argumentationen" bider sig selv i halen, og viser at der ingen sidste begrundelse er, kun at en uafsluttelig og konfliktuel ny sammenkædning er i gang.

Sidste mand ud er Hans-Jørgen Schanz, der gør sig nogle spekulationer over den nye franske filosofis omskiftelige tilværelse set fra et nordisk udkigstårn. I sin kikkert kan han hurtigt konstatere, at de sidste bevægelser i den såkaldte postmodernismedebat har gjort begrebsdifferentieringer nødigt. Og ved at vende kikkerten om kan han se nogle større slægtskaber og konvergenspunkter i en generation af filosoffer efter "the pragmatic turn". Erfaringen af sprogtab, kunstens eksperimenterende særstatus, defundamentalisering, provisorisk tænkning, som er sig bevidst, at der ikke findes nogen garanteret grund, kun processuelle og procedurale tilgange, uoversættelig- 
hed, radikal heterogenitet osv. forbinder Lyotard med bl.a. Adorno, Heidegger og Wittgenstein. Men der er også afdriftsmomenter: kunstens særstatus er neddæmpet, pathos og "Trauer" er udluftet, Wittgensteins udsagnsaskese er opgivet, Heideggers oprindelsesproblematik og dens forfaldstese er forladt, modernismens selv-højtidelighed og provinsielle skyttegravsmentalitet er forladt, til fordel for en fri udveksling på den internationale filosofis indre marked. Afslutningsvis er det Schanz' tese, at det ikke så meget er sprogfilosofien som i æstetikken, Lyotard har sin styrke og originalitet. Her demonstreres den maksimale kompetence til at "switche" over mellem forskellige genrer: maleri, musik, litteratur, arkitektur osv., hvor sammenhænge fremdrages uden at syntetiseres eller reduceres, og da slet ikke til filosofien som "basisviden".

I artiklen "Tiden, i dag" kommer så endelig mesteren selv til orde. En meget smuk og velvalgt tekst, som foruden en udfoldet tidsproblematik, man kun har anet konturerne af $\mathrm{i}$ tidligere tekster, nu også demonstrerer, at Lyotard har talenter for den filosofiske science fictions-genre, der overgår en chockeret Baudrillard med 4 1/2 millard år. Men som al god science fiction vedrører den post-solare exodus egentlig ikke en hypotetisk fremtid, men en aktuel (sam)tidskritik, med $\varnothing$ jeblikket som besindelsesmodus overfor den teknovidenskabelige diskurs' vækst henimod "absolut monade" (Leibniz), der stadigt mere effektivt fors $\varnothing$ ger at tilkaste og domesticere det sublime "nu" og som er ophørt med at lytte til dettes "sker det?", for i stedet blot at råbe i skoven for at høre sit eget svar. 